\title{
DROWNED KARST LANDSCAPE OFFSHORE THE APULIAN MARGIN (SOUTHERN ADRIATIC SEA, ITALY)
}

\author{
Marco Taviani ${ }^{1,2}$, Lorenzo Angeletti ${ }^{*}$, Elisabetta Campiani ${ }^{1}$, Alessandro Ceregato ${ }^{1}$, Federica

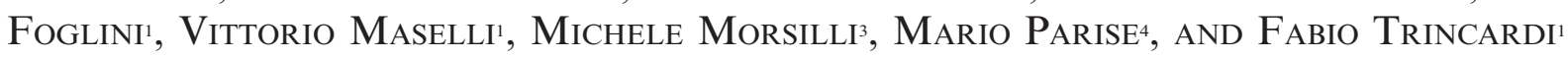

\begin{abstract}
The south Adriatic shelf offshore of the predominently carbonate Apulian coast is characterized by a peculiar rough topography interpreted as relic karst formed at a time of lower sea level. The study area covers a surface of about $220 \mathrm{~km}^{2}$, with depths ranging from 50 to $105 \mathrm{~m}$. The most relevant and diagnostic features are circular depressions a few tens to $150 \mathrm{~m}$ in diameter and 0.50 to $20 \mathrm{~m}$ deep thought to be dolines at various stages of evolution. The major doline, Oyster Pit, has its top at about $50 \mathrm{~m}$ water depth and is $20 \mathrm{~m}$ deep. It is partly filled with sediments redeposited by episodic mass failure from the doline's flank. Bedrock samples from the study area document that Plio-Pleistocene calcarenites, tentatively correlated with the Calcarenite di Gravina Fm, are a prime candidate for the carbonate rocks involved in the karstification, although the presence of other units, such as the Peschici or Maiolica Fms, is not excluded. The area containing this subaerial karst landscape was submerged about 12,500 years ago as a result of the postglacial transgression over the continental shelf.
\end{abstract}

\section{INTRODUCTION}

Karst landforms resulting from subaerial dissolution of carbonate rocks are distributed almost worldwide in carbonate countries, at places profoundly imprinting the landscape (Sweeting, 1973; Jennings, 1985; James and Choquette, 1988; Palmer, 1990; Ford and Williams, 2007). On modern continental margins, formerly subaerial carbonate karst features (sinkholes, dolines, fluted surfaces, etc.) occur as relics in subaqueous locations as a result of drowning related to continental margin tectonic evolution or sea-level fluctuations (Collina-Girard, 1996; Surić, 2002; van Hengstum et al., 2011). A field of sinkholes identified in the Straits of Florida at depths up to 500 meters is thought to have been formed entirely in a submarine environment in response to the paleohydrology of the carbonate Florida continental margin (Land et al., 1995; Land and Paull, 2000). On the other hand, many sinkholes reported from deep-water submerged locations have been interpreted as collapse structures due to the solution of underground evaporites (e.g., Biju-Duval et al., 1983; Taviani, 1984).

The Mediterranean Sea has a number of limestone coasts subject to karstification along its perimeter (e.g., Herak and Stringfield, 1972; Elhatip and Günay, 1998; Fleury et al., 2006; Mijatović, 2007; De Waele, 2009), but there are only a few records of drowned karst features: emblematic examples are the southern coast of France in the calanques Marseille region (Collina-Girard, 1996) and the northeastern Adriatic coast (Surić, 2002, 2005; Surić et al., 2005; Surić and Juračić, 2010), which represents the seaward expansion of the classical karst area in the Croatian Dinarides (Cvijić, 1893).

Here we report the identification of a drowned karst landscape in the south-western Adriatic Sea in the submarine topography just offshore the prevalently carbonate coast of the Gargano Promontory (Fig. 1).

\section{Materials And Methods}

The study area was surveyed during cruise CNR002 in March 2002 on board RV OdinFinder and cruises ARCO and ARCADIA of RV Urania in December 2008 and March 2010, respectively. The region containing karst features was mapped by means of multibeam bathymetry, and the superficial geology was imaged through a chirpsonar profiler and sidescan sonar. Swath-bathymetry data were acquired using a Kongsberg Simrad EM3000 multibeam echo-sounder with a nominal sonar frequency of $300 \mathrm{kHz}$ and angular coverage sector of 127 beams per ping of $1.5^{\circ}$. Chirp-sonar profiles were obtained using a hull-mounted sixteen-transducer source with a sweepmodulated $2-7 \mathrm{kHz}$ outgoing signal equivalent to a $3.5 \mathrm{kHz}$ profiler. Sidescan sonar profiles were obtained by a towed LG1000 EG\&G 260 sidescan sonar with a frequency of $100-500 \mathrm{kHz}$. Water-column attributes were measured with a Conductivity/Temperature/Depth profiler (CTD) using a Seabird SBE 11 PLUS using the SEASAVE V5.33 software.

Bottom sampling was performed using 1.2 ton gravity corer, large-volume grab, chained geological dredge, and epibenthic hauls (Table 1). Visual inspection of the main doline was conducted using the ROV Prometeo equipped

\footnotetext{
* Corresponding author: lorenzo.angeletti@bo.ismar.cnr.it

${ }^{1}$ ISMAR-CNR, Via Gobetti 101, Bologna, Italy

${ }^{2}$ Woods Hole Oceanographic Institution, 266 Woods Hole Rd, Woods Hole, Ma. 02543, USA

${ }^{3}$ Dipartimento di Scienze della Terra, Università di Ferrara, Via G. Saragat 1, 44100 Ferrara, Italy

${ }^{4}$ IRPI-CNR, Via Amendola, 122, 70126 Bari, Italy. m.parise@ba.irpi.cnr.it
} 


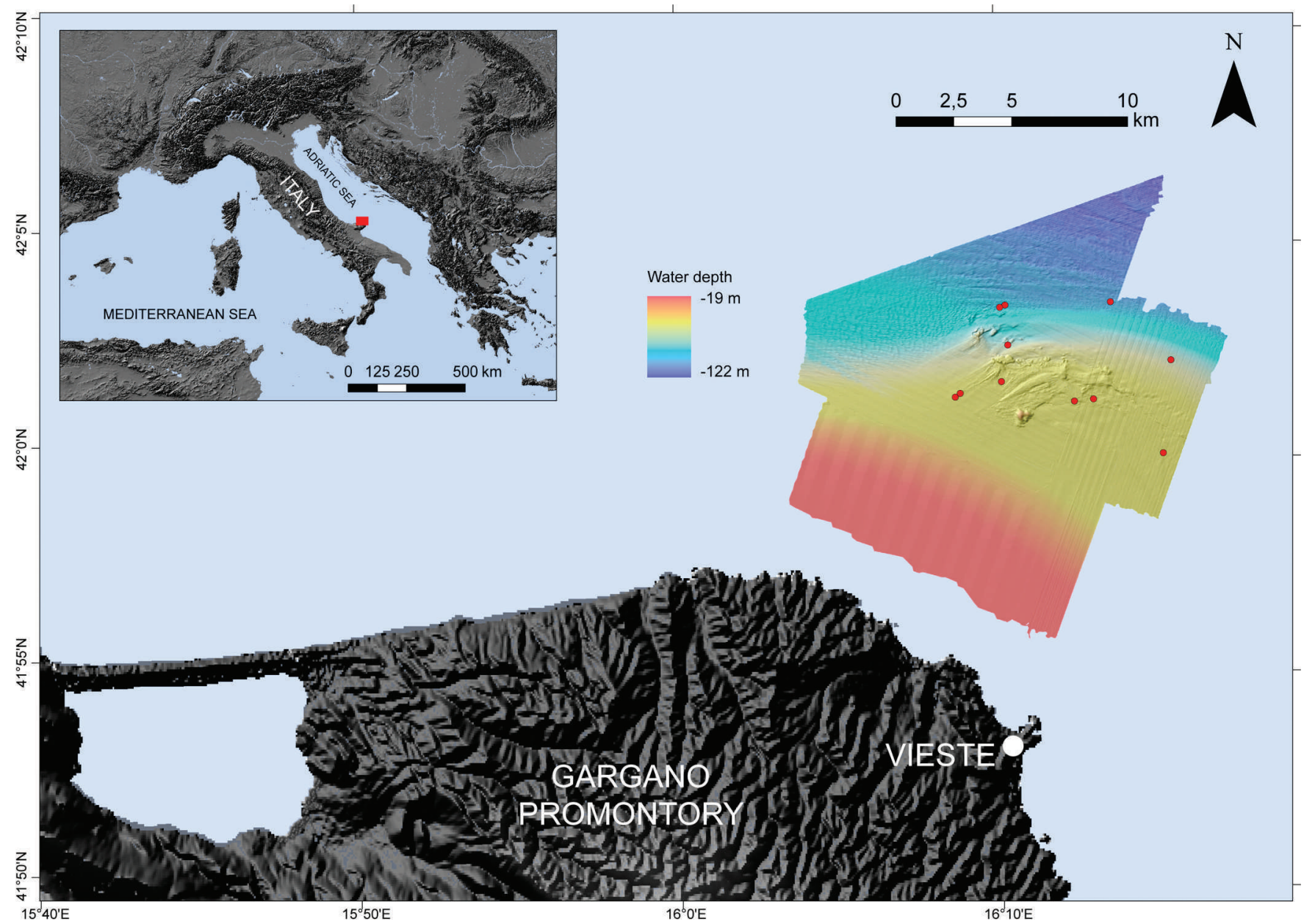

Figure 1. Map showing the location of the drowned karst area offshore the Gargano Promontory in the southern Adriatic Sea discussed in this article (red spots = dolines); inset, the Mediterranean basin with rectangle showing the same area magnified in the figure.

with a Panasonic $1 / 3$ in. CCD camera and ROV Pollux (Global Electric Italiana) equipped with a Nikon D80 10megapixel digital camera and a SonyHDR-HC7 highdefinition camera. ${ }^{14} \mathrm{C}$-AMS dating of mollusk shells was carried out at the Poznán Radiometric Laboratory, Poland. Radiocarbon results in Table 2 are reported as raw ${ }^{14} \mathrm{C}$ ages given in ${ }^{14} \mathrm{C}$ years $\mathrm{BP}$, and as calendar year estimates (cal yrs BP) after calibration; BP refers to AD 1950.

\section{RESULTS}

\section{Morphology of Drowned Karst Features}

The continental shelf offshore northeast of the Gargano Promontory is characterized by a relatively flat erosional surface at between 45 and $60 \mathrm{~m}$ water depth. Landward of this area, a mass of late Holocene deposits reaches a thickness of $25 \mathrm{~m}$ and displays a clinostratified internal geometry (Cattaneo et al., 2003). At water depths greater than $70 \mathrm{~m}$, late-Holocene muddy deposits are draped on the pre-existing erosional morphology of the area (Cattaneo et al., 2003). Between the two areas of deposition, the flat area is barren of modern muddy late-Holocene sediment, suggesting that, in this region, the Adriatic Coastal Current accelerating around the Gargano Promontory does not allow permanent deposition of mud, as predicted by oceanographic models (Magaldi et al., 2010). The barren area is characterized by the presence of shell gravel, bioclastic sand, rhodoliths, live oyster aggregates, and by an area of outcropping cemented rocks with a high backscatter on sidescan sonar and a rugged topography suggestive of differentially cemented or differentially eroded stratified rocks.

The study area with karst morphology is located on the Apulian continental shelf about 6 nautical miles $(10 \mathrm{~km})$ offshore the Gargano Promontory (Fig. 1). The area covers about $220 \mathrm{~km}^{2}$, with water depths ranging from approximately 50 to $105 \mathrm{~m}$. The detailed bathymetric map reveals a complex, rough sea-bottom topography, strongly sculptured by small (1 to $5 \mathrm{~m}$ ) grooved relief, often striking 


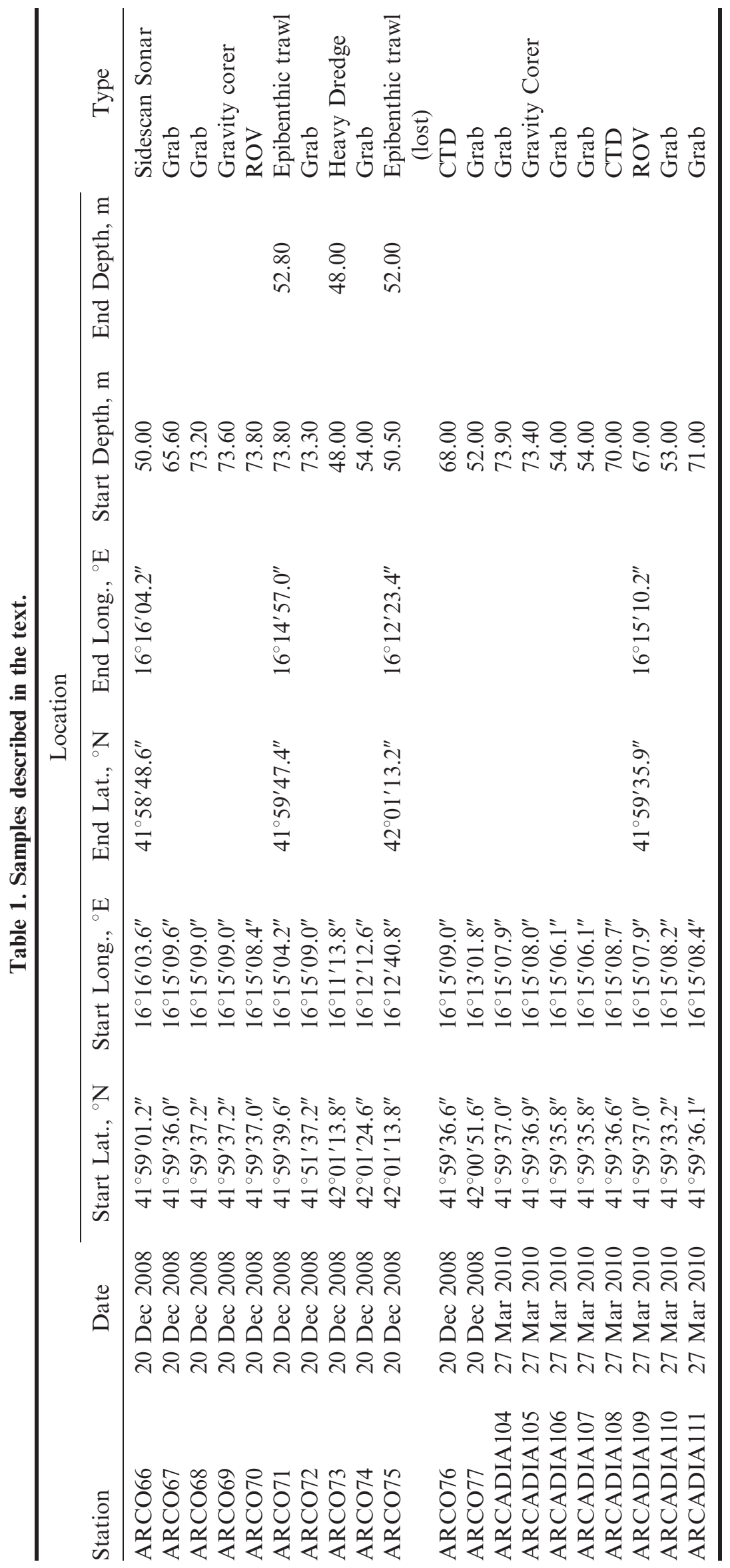




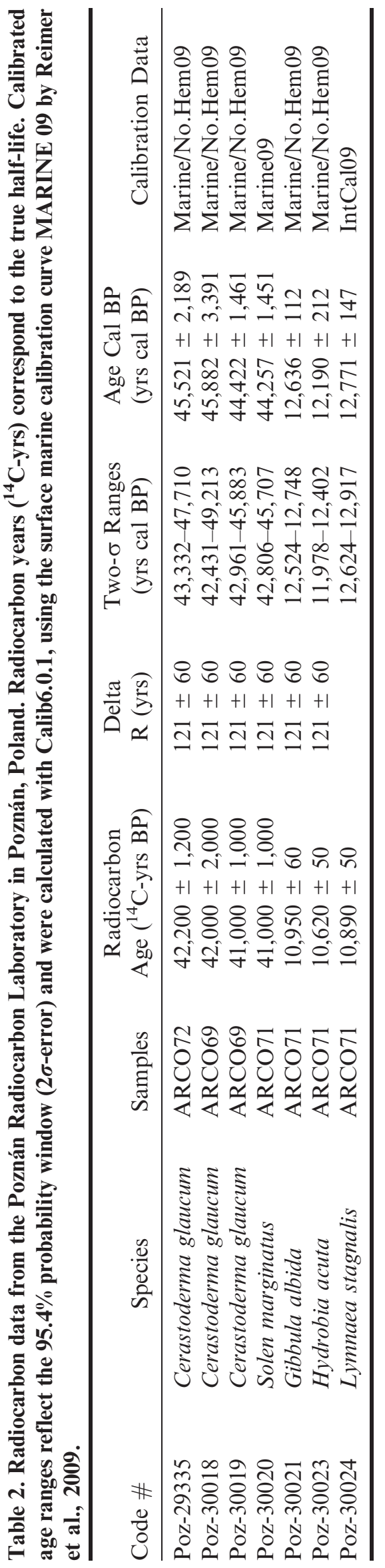

NE-SW and ENE-WSW, and punctuated by circular depressions (Figs. 2, 3, 4). This topography is in our view related to former karstification, and arguments to support this view are discussed below.

\section{Dolines}

One of the main morphologies identified on the Apulian shelf is circular depressions interpreted as dolines at various stages of evolution (Figs. 2, 4; Table 3). Some dolines are clearly aligned along a NE-SW direction (Fig. 5). This is an indication that their formation was controlled by structural or stratigraphic factors, as has often been documented inland (e.g., Nisio, 2008). We counted eleven major circular depressions ranging from 155 to 50 meters in diameter and from about 0.5 to 20 meters in depth (Figs. 2, 4, 5; Table 3). Only one doline is as much as 20 meters deep (Figs. 4, 5). This most prominent doline is named Oyster Pit, as its flanks and bottom are intensely colonized by Neopycnodonte cochlear oyster reefs and clumps (Taviani et al., 2009). Because Oyster Pit is by far the deepest and best-developed doline in the study area, most of the following discussion is focused on it.

\section{Oyster Pit}

This doline is characterized by an almost circular shape with a diameter of $120 \mathrm{~m}$, relatively steep flanks (about $25^{\circ}$ dip), and a rather flat bottom. Its top is at about $49 \mathrm{~m}$ depth and its bottom is about $73 \mathrm{~m}$ deep (Figs. 4, 5).

The ROV visual inspection of the entire doline provided no obvious information on the nature of the karstified bedrock because no bare rock is exposed anywhere. ROV images reveal that the bottom is carpeted by intensely bioturbated sandy sediments (Fig. 6) peppered by recent and pre-modern shells and pebbles that often serve as host to living epifauna (Figs. 6, 7B). The upper part of the doline between 55 and $60 \mathrm{~m}$ depth is characterized by similar deposits, at places clearly visible when entrapped by modern oyster rims (Fig. 6C). The pre-modern shelly component (Fig. 7B) is mostly composed of brackish/ lagoonal (Loripes lucinalis, Cerastoderma glaucum, Gastrana fragilis, Abra segmentum, Gibbula albida, Hydrobia cf. acuta, Bittium reticulatum) and shallow marine (e.g., cf. Chamelea gallina, Donax trunculus, Ensis sp., Solen marginatus, Gibbula albida, Nassarius mutabilis, Cyclope neritea) mollusks. Calibrated ${ }^{14} \mathrm{C}$-AMS dating (Table 2) of these pre-modern shells (Fig. 7) indicates that these were of late Pleistocene age, with Cerastoderma (Station [st.] ARCO72, -73.4 m; Fig. 7B) and Solen marginatus (st. ARCO71, -73.8/-52.8 m) having calibrated ages of $45,521 \pm 2,189 \mathrm{yrs}$ and 44,257 $\pm 1,451 \mathrm{yrs}$, respectively, while Hydrobia acuta (st. ARCO71) had a calibrated age of 12,190 \pm 212 years and Gibbula albida (st. ARCO71) provided a calibrated age of 12,636 \pm 112 yrs. Pebbles from the doline bottom and flanks are well rounded and often spherical, with dimensions ranging from 2 to $65 \mathrm{~mm}$, 


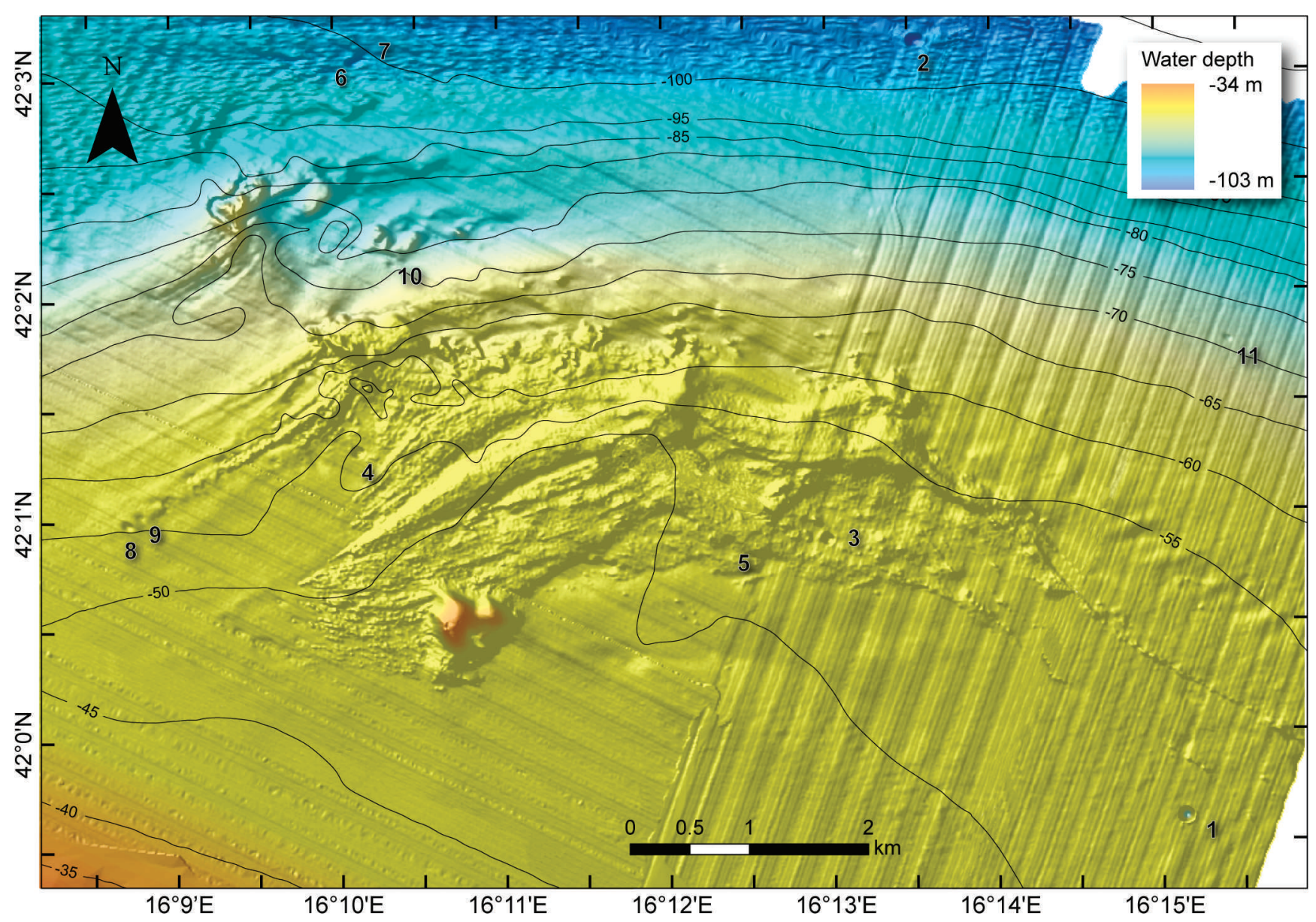

Figure 2. Multibeam-sonar map of the study area showing the complex, rough topography punctuated by many circular depressions interpreted as dolines. Major dolines are numbered and their characteristics are reported in Table 3; 1 is Oyster Pit, the major doline in the area (see text); and 10 is a double doline formed by two partly coalesced depressions. Note NE-SW alignment of circular depressions, including dolines 8 and 9 . Isobath spacing is $\mathbf{5}$ m.

occurring loose or as conglomerates, lithologies, dominantly limestone, and chert (Fig. 7A).

Chirp-sonar profiles provide a view of the subsurface geological setting, documenting a relatively thin sedimentary infilling. Profile AR-246 (Fig. 8) highlighted the stratigraphy of the Oyster Pit area. Post-glacial transgressive sediments characterize the seafloor outside the doline, indicating sediment undersupply during the late Holocene. The doline's bottom is characterized by a chaotic seismic signature. Two gravity cores obtained from the bottom of Oyster Pit at $73 \mathrm{~m}$ depth shed light on the nature of this sequence. Core ARCO 69 was collected at $41^{\circ} 59.62^{\prime} \mathrm{N}$ $16^{\circ} 15.15^{\prime}$ E (recovery $134 \mathrm{~cm}$; Fig. 9A), while core ARCADIA A105 was collected at $41^{\circ} 59.62^{\prime} \mathrm{N}-16^{\circ} 15.13^{\prime}$ E (recovery $259 \mathrm{~cm}$; Fig. 9B). Both cores contained a rather similar sequence. The main motif of the most recent infilling of Oyster Pit is a repetition of sandy to gravelly deposits containing Pleistocene brackish/lagoonal and shallow marine mollusks (Loripes lucinalis, Cerastoderma glaucum, Hydrobia cf. acuta, Bittium reticulatum etc.). These deposits alternate with fine-grained sediments. Two
Cerastoderma shells from core ARCO-69 (Fig. 9A) have been dated at 44,422 $\pm 1,461$ yrs cal BP (core depth 22 $23 \mathrm{~cm}$ ) and 45,882 \pm 3,391 yrs cal BP (core depth 95$96 \mathrm{~cm}$ ), respectively. Pebbles associated with the infilling units likely originate from Mesozoic (limestone with calcispheres and chert: Maiolica Fm; floatstone and rudstone: Montesacro Fm or Ripe Rosse Fm) and Neogene (Pietra Leccese or Calcareniti di Apricena Fm) units cropping out on the adjacent Gargano Promontory. Most probably Pleistocene brackish/lagoonal deposits were episodically remobilized from the upper flanks and external rim of the doline (Fig. 6C). This phenomenon is active currently, because modern Neopycnodonte cochlear oyster shells contribute to these sediments (Fig. 9). In short, Oyster Pit seems to be at present a moderately quiet environment subject to occasional redeposition of material from its flanks.

Interestingly, the shelly assemblages recovered from the bottom of Oyster Pit contain terrestrial (Truncatellina sp., Chondrula tridens, Xerotricha sp.) and freshwater (Lymnaea stagnalis, Planorbis sp., Gyraulus crista, Acroloxus lacustris, 


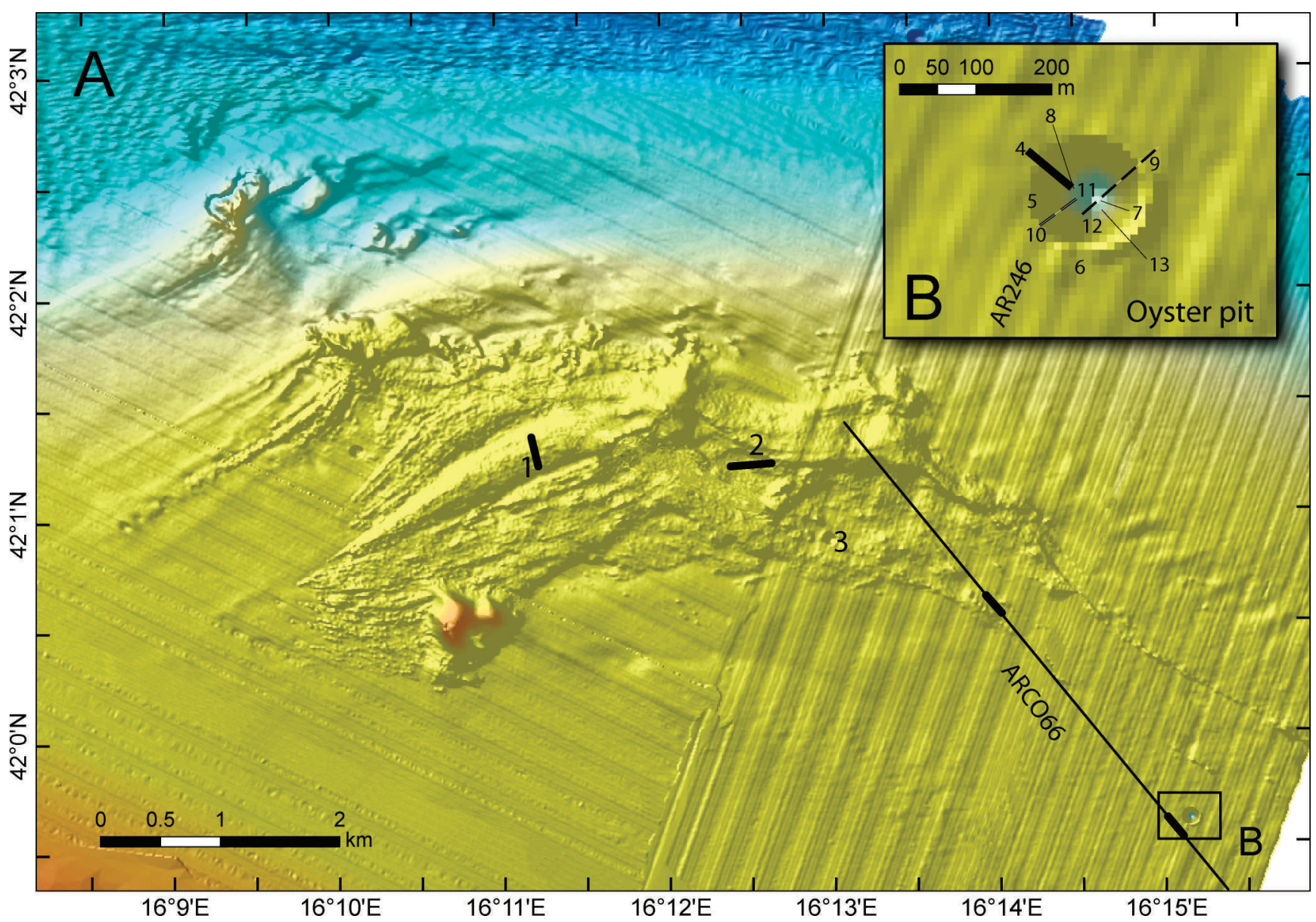

Figure 3. A: Multibeam-sonar map of the study area showing location of bottom samples, CTD (Conductivity/Temperature/ Depth) casts, ROV, Chirp (AR246), and sidescan sonar (ARCO66) profiles discussed in the text (see Table 1); st. 73 and st. 78 provided the Pleistocene calcarenites (see Fig. 10 and text) that are thought to form the superficial bedrock of the submerged karst area. Inset B is the magnification of the Oyster Pit doline (marked by a rectangle) where most of the sampling took place. Stations are: 1 = ARCO73 (heavy dredge); 2 = ARCO75 (epibenthic trawl, lost); 3 = ARCO74 (grab); $4=$ ARCO77 (grab); 5 = ARCO71 (epibenthic trawl); 6 = ARCADIA106 (grab), 107 (grab); 7 = ARCADIA110 (grab); 8 = ARCO67 (grab); $9=$ ARCO68 (grab), 69 (gravity core), 72 (grab), ARCADIA105 (gravity core); 10 = ARCADIA109 (ROV); $11=$ ARCO70 (ROV); 12 = ARCO76 (CTD), ARCADIA104 (grab), 108 (CTD); 13 = ARCADIA111 (grab), 112 (grab).

Theodoxus sp., etc.) gastropods (Fig. 7D), as well as Candona ostracods and oogones of Characeae. One shell of Lymnaea stagnalis provided a calibrated age of 12,771 \pm 147 yrs BP (st. ARCO71). This fossil assemblage indicates that immediately before its postglacial flooding, the doline may have hosted a shallow lake or pond surrounded by xerophilic vegetation.

Calcarenites and sandstones were found in samples from the floor of Oyster Pit, often fouled with modern epifauna such as oysters and corals (Fig. 10). The poorly lithified sandstones, together with co-occurring dark, muddy sands, entrap articulated or loose brackish/lagoonal shells (Loripes and Cerastoderma: Fig. 7E, F) and are possibly coeval with the older brackish/lagoonal faunas described above. Calcarenites are weakly cemented medium- to coarse-grained carbonate (at times arkosic) sandstones embedding highly decalcified sub-littoral marine mollusks of likely Pleistocene age (e.g., Acanthocardia sp.: st. ARCADIA111; Turritella sp.: st. ARCO72, Fig. 10C, D).

\section{Discussion}

\section{Geologic Setting}

The study area offshore the Gargano coast is part of the southern Apennine foreland. The Gargano Promontory is built mainly of carbonate rocks belonging to a large paleogeographical domain known as Apulia Carbonate Platform that was part of the southern margin of the Tethys Ocean during the Mesozoic (Eberli et al., 1993). The backbone of the Gargano Promontory consists of various stratigraphic units, Late Jurassic to Eocene in age, deposited in inner-platform and basin settings (Bosellini et al., 1999), and of scattered outcrops of Oligo-Miocene and Plio-Pleistocene sediments (Casolari et al., 2000). 


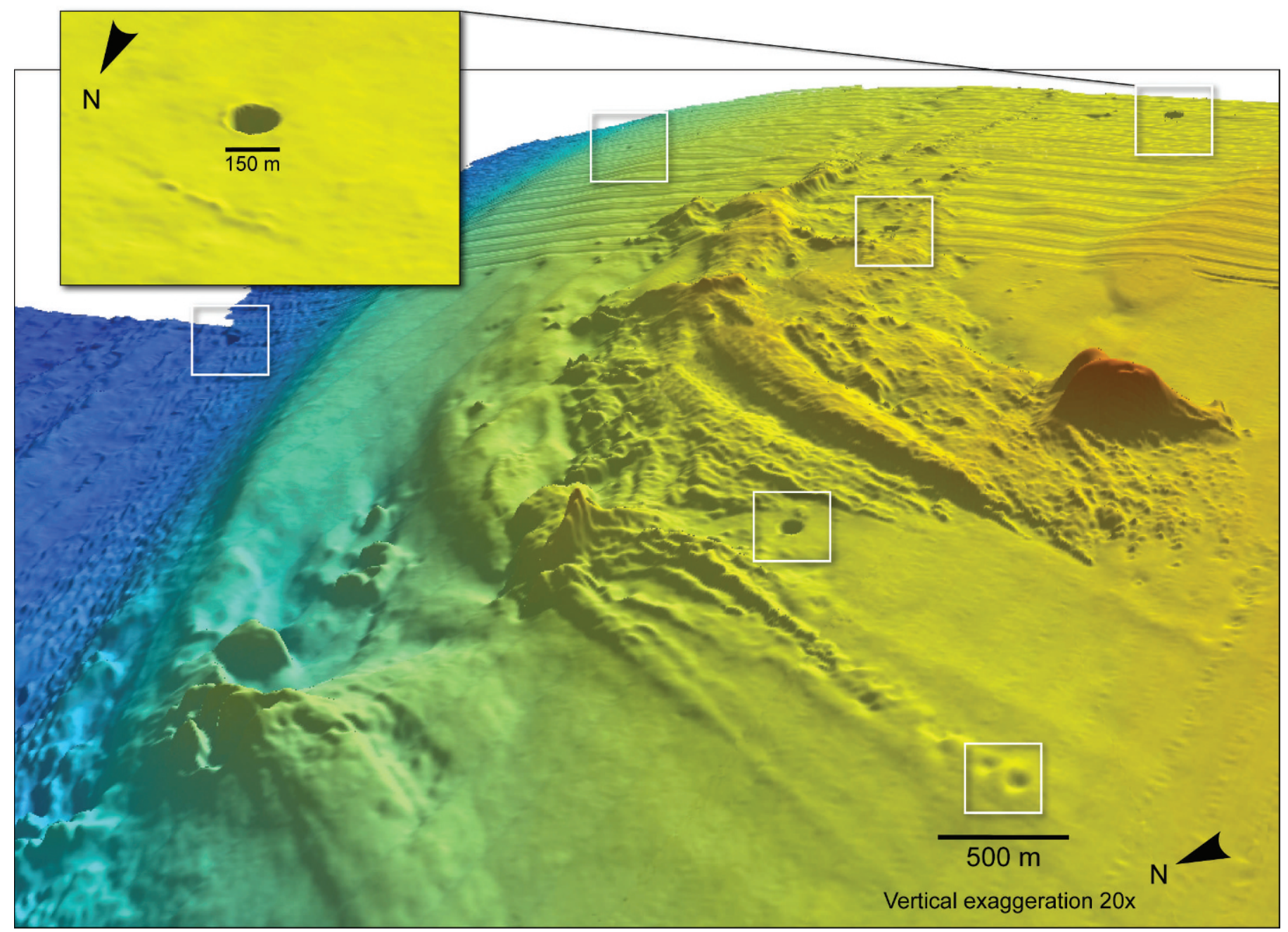

Figure 4. Reconstruction of the study area as seen as a 3-D view from the west showing the aligned dolines 8 and 9 in the foreground and other main dolines, including the almost solitary Oyster Pit in the background (inset).

Table 3. Location and main characteristics of major dolines identified in the drowned karst area offshore Gargano Promontory. Oyster Pit is number 1. See Figure 2 and text.

\begin{tabular}{lcccccc}
\hline & \multicolumn{5}{c}{ Location } \\
\cline { 2 - 7 } StationNo. & Lat., ${ }^{\circ} \mathrm{N}$ & Long., ${ }^{\circ} \mathrm{E}$ & Top, mbsl & Bottom, mbsl & Depth, m & Diameter, m \\
\hline 1 & $41^{\circ} 59^{\prime} 36.5^{\prime \prime}$ & $16^{\circ} 15^{\prime} 08.9^{\prime \prime}$ & 54.4 & 73.8 & 19.3 & 155.0 \\
2 & $42^{\circ} 03^{\prime} 08.6^{\prime \prime}$ & $16^{\circ} 13^{\prime} 33.1^{\prime \prime}$ & 102.2 & 106.5 & 4.3 & 150.0 \\
3 & $42^{\circ} 00^{\prime} 53.5^{\prime \prime}$ & $16^{\circ} 12^{\prime} 58.9^{\prime \prime}$ & 51.7 & 55.0 & 3.3 & 125.0 \\
4 & $42^{\circ} 01^{\prime} 18.4^{\prime \prime}$ & $16^{\circ} 10^{\prime} 07.7^{\prime \prime}$ & 55.7 & 58.5 & 2.8 & 120.0 \\
5 & $42^{\circ} 00^{\prime} 52.9^{\prime \prime}$ & $16^{\circ} 12^{\prime} 22.9^{\prime \prime}$ & 49.6 & 51.3 & 1.8 & 109.0 \\
6 & $42^{\circ} 03^{\prime} 04.6^{\prime \prime}$ & $16^{\circ} 10^{\prime} 06.9^{\prime \prime}$ & 98.4 & 100.6 & 2.2 & 100.0 \\
7 & $42^{\circ} 03^{\prime} 06.7^{\prime \prime}$ & $16^{\circ} 10^{\prime} 11.4^{\prime \prime}$ & 99.0 & 100.0 & 1.0 & 100.0 \\
8 & $42^{\circ} 00^{\prime} 58.9^{\prime \prime}$ & $16^{\circ} 08^{\prime} 43.6^{\prime \prime}$ & 52.8 & 53.9 & 1.1 & 90.0 \\
9 & $42^{\circ} 01^{\prime} 01.1^{\prime \prime}$ & $16^{\circ} 08^{\prime} 48.6^{\prime \prime}$ & 53.3 & 54.0 & 0.7 & 70.0 \\
10 & $42^{\circ} 02^{\prime} 09.3^{\prime \prime}$ & $16^{\circ} 10^{\prime} 20.9^{\prime \prime}$ & 72.4 & 72.8 & 0.4 & 60.0 \\
11 & $42^{\circ} 01^{\prime} 46.4^{\prime \prime}$ & $16^{\circ} 15^{\prime} 26.6^{\prime \prime}$ & 70.7 & 71.7 & 1.0 & 50.0 \\
\hline
\end{tabular}



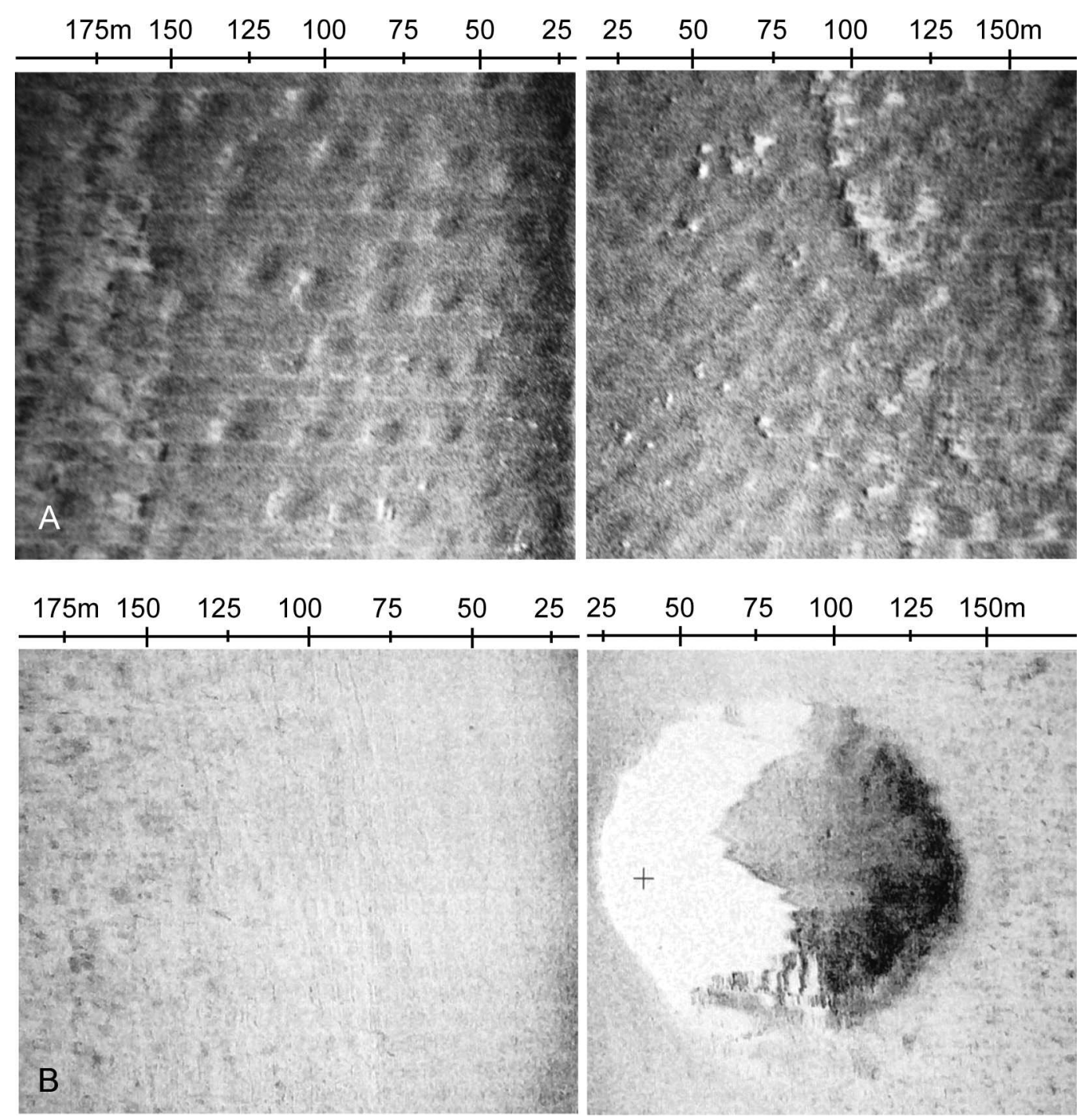

Figure 5. Details of sidescan-sonar images of the offshore drowned karst area made during the ARCO66 traverse shown in Figure 3, where the locations are indicated by the thickened portions of the traverse line. (A) A field of small circular depressions up to about $20 \mathrm{~m}$ in diameter, resulting in a distinct pitted seascape. (B) The Oyster Pit doline.

The geologic setting of the region containing the submerged karst features can be reasonably constrained by combining information provided by exploratory commercial wells, reflection-seismic data, and on-shore outcrops (see Argnani et al., 2009, for a review of the Adriatic offshore stratigraphy). The wells closest to the study area are Gargano Est Marine 1 (about $43 \mathrm{~km} \mathrm{NE}$ ), Cigno Mare 1 (about $47 \mathrm{~km} \mathrm{ESE}$ ), and Gondola 1 bis (about $52 \mathrm{~km} \mathrm{SE}$ ). The stratigraphic record intercepted by these wells documents various units deposited in a basin setting from the Lower Jurassic at least (De Dominicis and Mazzoldi, 1987; De Alteriis and Aiello, 1993; Argnani et al., 2009). Evidence of shallow water is limited to times in the middle Pliocene (Cigno Mare 1) and early Pleistocene (Gargano Est Marine 1), marked by the deposition of few tens of meters of skeletal limestone (Calcarenite di Gravina Fm).
In particular, this sector of the Adriatic Sea is formed by an uppermost sequence (130 to $200 \mathrm{~m}$ ) of Plio-Pleistocene clastics (Argille Azzurre Fm), followed by more than $50 \mathrm{~m}$ of Plio-Pleistocene skeletal limestone (Calcarenite di Gravina Fm), Tortonian green marls and limestones (Bisciaro Fm), upper Oligocene marls (Scaglia Cinerea Fm, not always present). These Tertiary units unconformably cap over Upper Cretaceous (Cenomanian to Coniacian) chert-bearing chalky limestone (Scaglia Fm), Lower Cretaceous marls and marly limestone (Marne a Fucoidi Fm), chert-bearing micritic limestone (Maiolica Fm), and older Mesozoic carbonates.

The stratigraphic succession cropping out in the eastern corner of the Gargano Promontory between Vieste and Peschici (Bosellini and Morsilli, 2001) exposes only four main litostratigraphic units, i.e., the Maiolica Fm, the 

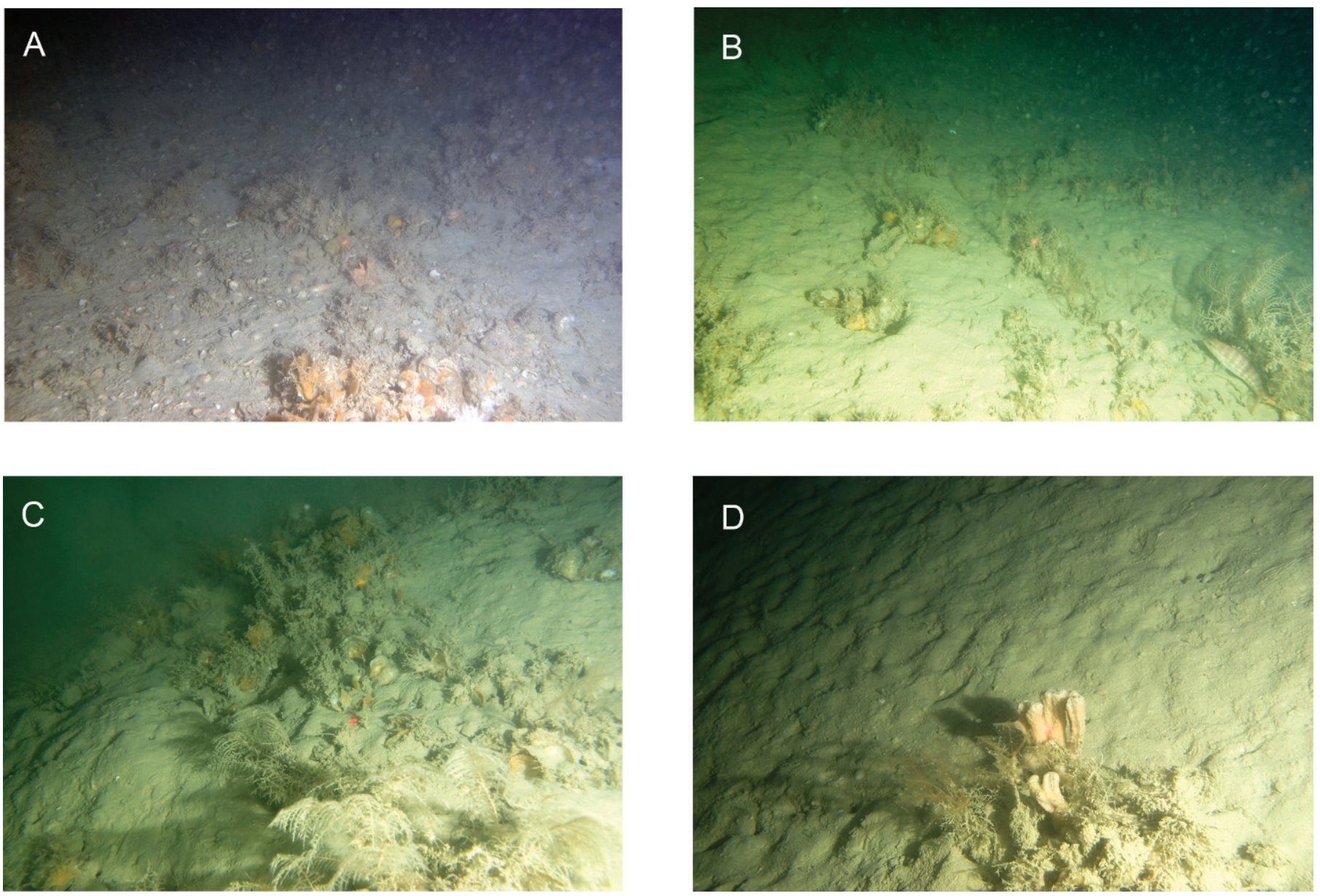

Figure 6. Views of the Oyster Pit doline. (A) Sandy bottom, depth about 70 m, with sparse living epifauna, pebbles (p), and valves of older lagoonal shells (c). (B) Sandy bottom with sparse epifauna (b). (C) Flank of the doline, about $55 \mathrm{~m}$. Note fringe of living oysters and other epifauna damming older lagoonal shells (c). (D) Bioturbated sandy bottom with clusters of oysters, sponges, and hydroids; note parallel small bedforms. All photographs taken by S. Canese and L. Rossi during cruise ARCADIA using the ISPRA ROV Pollux.

Marne a Fucoidi Fm, the Scaglia Fm, and the Peschici Fm (thin- to thick-bedded lime mudstone, with calcarenite and breccia intervals). That last, middle Eocene unit crops out extensively inland and is also found in the Tremiti and Pianosa Islands, some tens of kilometers toward the NNW, but was not recorded in the offshore wells. The areal distribution of the unit (De Dominicis and Mazzoldi, 1987) suggests a possible extension of this formation to the study area offshore.

\section{Apulian Karst}

The dominantly carbonate Apulian landscape is profoundly imprinted by karst features (Parise, 2008a). Most of the Gargano Promontory shows surface and subsurface karst landforms related to dissolution processes of variable intensity. These are dominantly dolines, locally accompanied by poljes, and by a remarkable number of underground karst systems, with more than 700 caves charted so far
(Fusilli, 2007). Dolines range from solution dolines to collapse features, representing almost the whole spectrum of types described by Waltham et al. (2005). This is the case, for instance, in the so-called Chiancate area, where the density of dolines reaches its maximum, over 100 per km² (Baboci et al., 1991). Most dolines developed in the Jurassic and Cretaceous limestones are solutional in origin and create circular depressions with slightly inclined margins, have a flat bottom a few tens of meters wide, and are up to 20 meters deep. Collapse dolines are also present, showing features significantly sharper, usually represented by steeply inclined to subvertical walls; the best example in Gargano is the Dolina Pozzatina, $600 \mathrm{~m}$ wide and $130 \mathrm{~m}$ deep (Castiglioni and Sauro, 2000; Parise, 2008b).

Analogous features can be observed farther south, in the Murge plateau (Fig. 11), and represent the most renowned examples of the Apulian karst landscape (Parise, 2008b, 2011). All such landforms affect the Mesozoic 


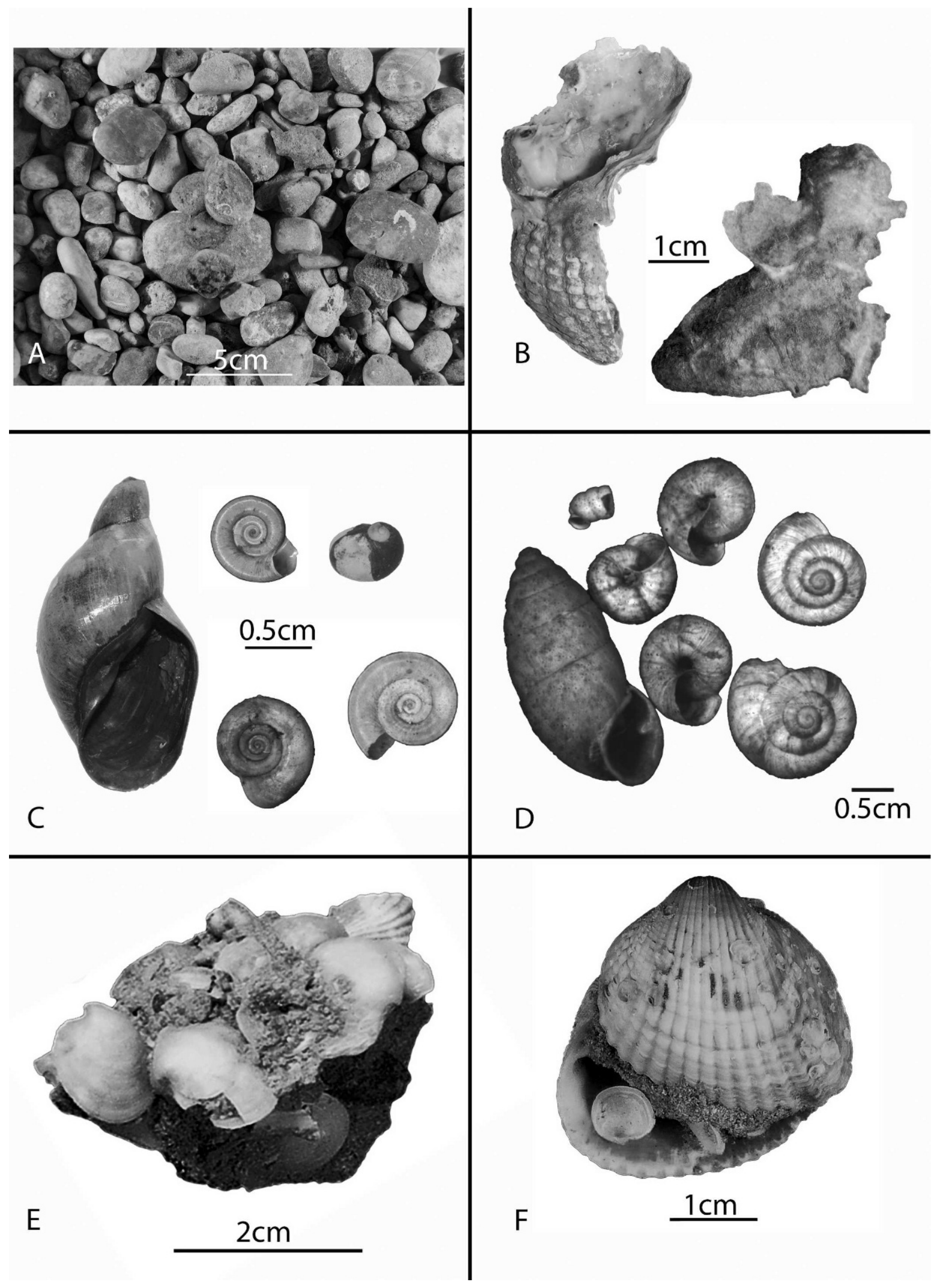

Figure 7. Examples of rocks and fossil fauna recovered from the bottom of Oyster Pit. (A) Pebble assemblage after washing of sandy matrix and removal of bioclastic particles. Notice the high roundness and sphericity and low diversity of the pebbles composed of Mesozoic chert and limestones (ARCADIA104). (B) Old brackish/lagoonal shells (left, Cerastoderma, ARCO72,

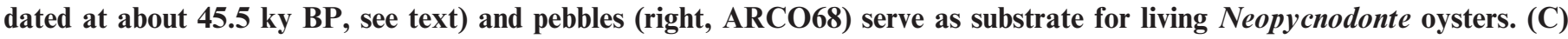




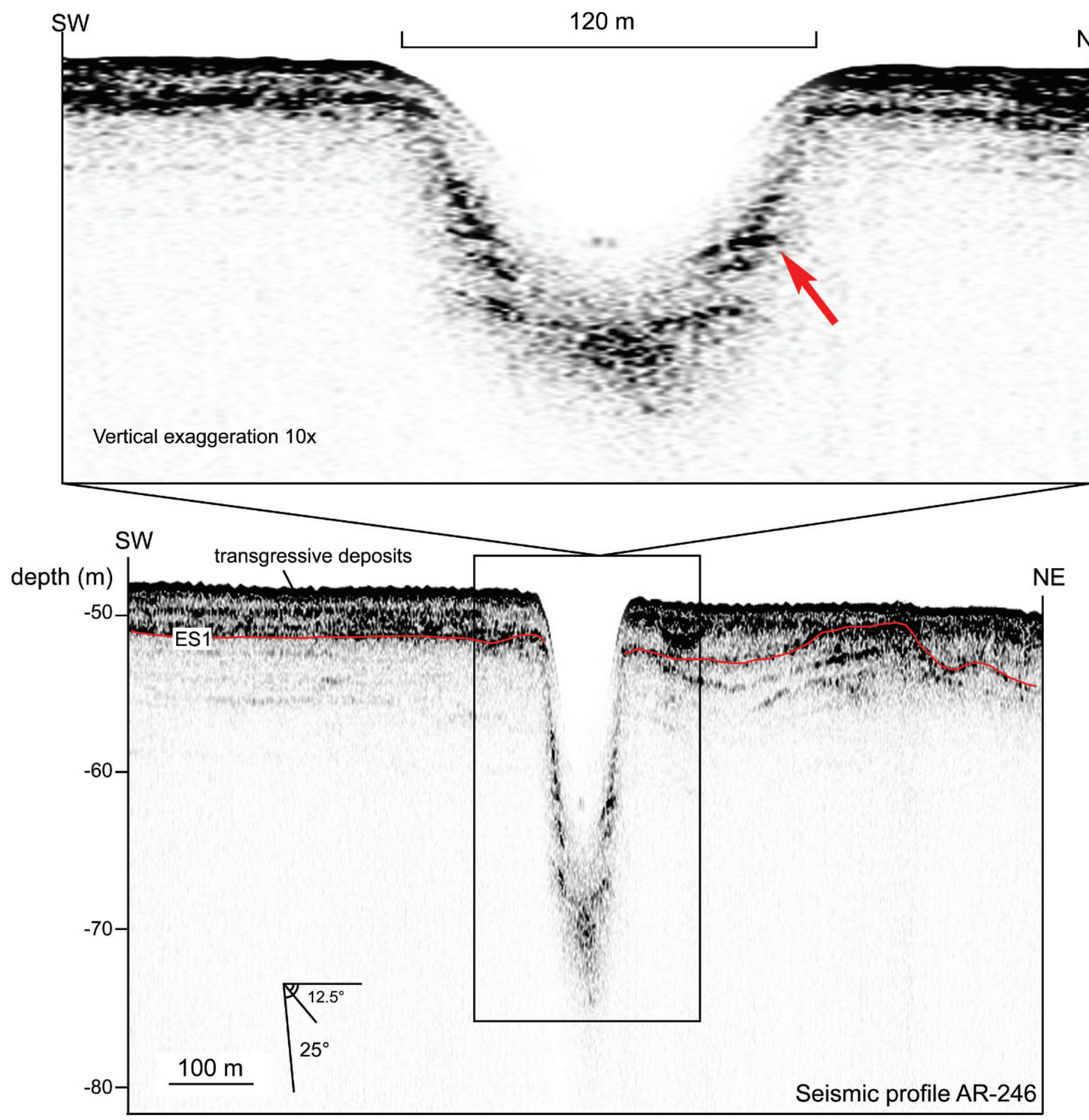

Figure 8. High-resolution chirp-sonar profile AR-246 (cruise ARCADIA; see Fig. 3 for its location) highlighting the stratigraphy of the Oyster Pit doline. Outside the doline, the area is characterized by about 3 meters of transgressive deposits, covering the ES1 erosional surface connected to the last sea-level lowstand (Ridente and Trincardi, 2005). The seismic profile shows that the doline is filled by a few meters of chaotic deposits at least, and, possibly, blocks (arrow) connected to mass gravity processes.

$\leftarrow$

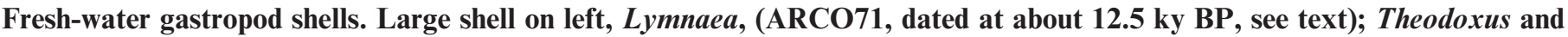
Planorbidae (ARCO67). (D) Shells of terrestrial pulmonate gastropods (Chondrula, large shell on the left, Truncatellina, upper left, and Xerotricha) ARCO67. (E) Concretioned sandstone embedding paired and disarticulated shells of the brackish/ lagoonal bivalves Loripes and Cerastoderma (upper right), from ARCO72. (F) Large articulated shell of the brackish/lagoonal bivalve Cerastoderma infilled with Loripes-bearing sandstone (ARCADIA104). 

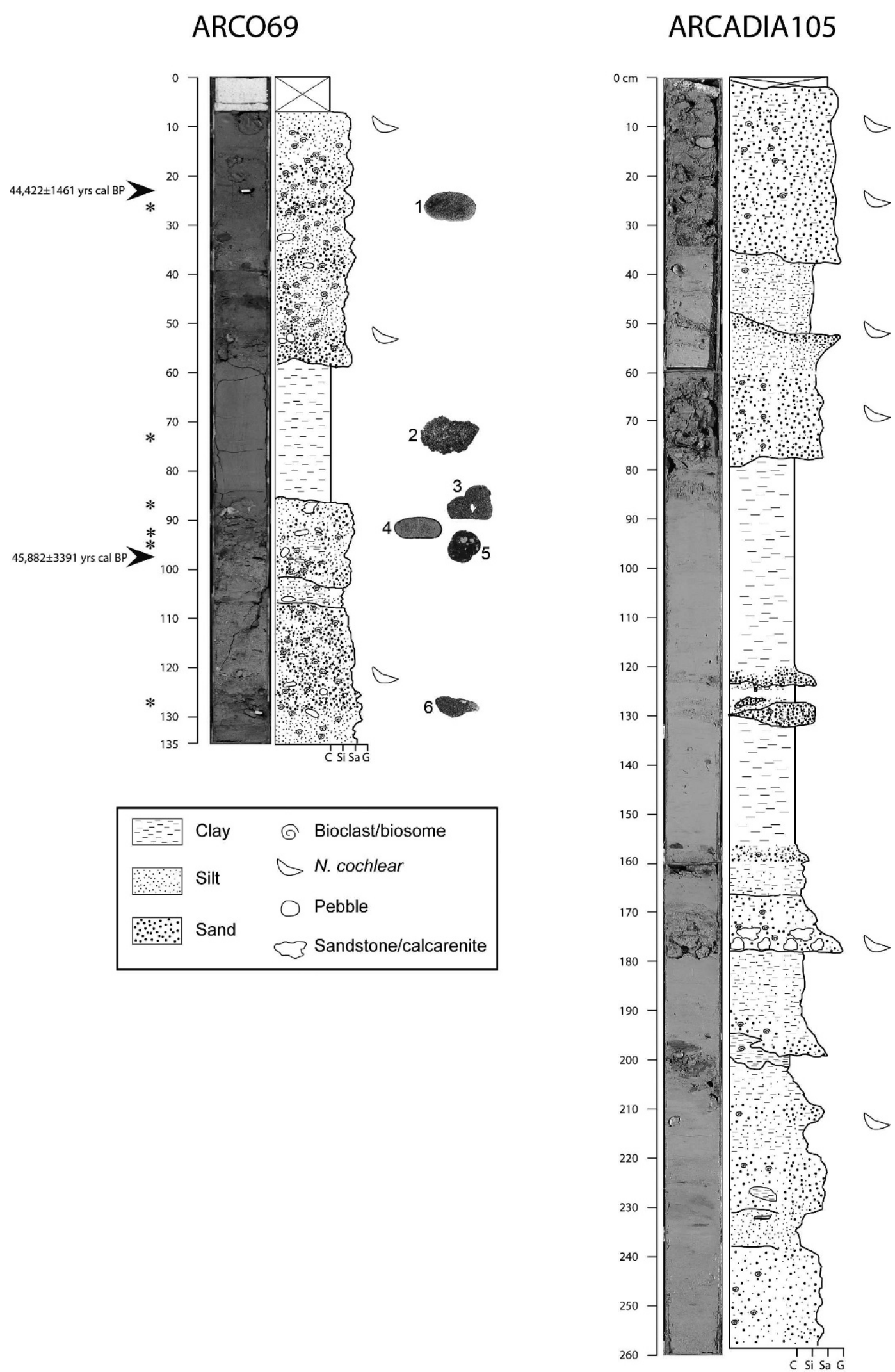

Figure 9. Photographic (left) and interpreted (right) logs of cores from Oyster Pit. Multiple mass gravity deposits are evident, involving old (pebbles, brackish/lagoonal loose shells and sandstones) and modern (e.g., Neopycnodonte cochlear) components. (A) core ARCO69, recovered from the bottom of Oyster Pit at $73.6 \mathrm{~m}$ depth. Sectioned pebbles within the core are shown and their source formation based on thin section reported. Key: 1. Limestone with calcisphere and rare planktonic forams (Maiolica 
limestones, while farther south, in the Salento Peninsula, different types of dolines, both inland and along the coastline, are developed in younger rocks (Delle Rose and Parise, 2002; Bruno et al., 2008; Del Prete et al., 2010). In particular, the Plio-Pleistocene Calcareniti di Gravina Fm is mostly affected by dolines related to the solution, suffusion, and dropout types (Waltham et al., 2005), showing subtle morphology and reduced sizes, on average up to $10 \mathrm{~m}$ wide and $4 \mathrm{~m}$ deep. Nevertheless, the same rocks may be locally involved in collapses related to the presence of underground caves, whose evolution may result in upward stoping of the cave ceilings until it reaches the ground surface and produces the final collapse. Some dolines display morphological features similar to Oyster Pit, such as a well-defined circular shape, steep walls (often subjected to further minor failures due to tensional release), and breakdown material at the bottom. The bottom may be partially or totally covered by debris or alluvial sediments, so that nowadays the doline's bottom appears flat or smooth. The size of these collapse dolines is between 5 and 30 meters in width and 3 and 15 meters in depth (Parise, 2008a, b).

\section{Drowned Offshore Karst}

In the investigated area, Mesozoic rocks only occur as highly rounded pebbles in coastal deposits. On the contrary, Pleistocene calcarenites were found in onshore and offshore wells. Moreover, sampling inside the dolines (Fig. 10) and on the topographically rough area on the erosional surface (Fig. 10) provided marine calcarenites that could be correlated to the Calcareniti di Gravina Fm. Therefore, at the present state of knowledge, we hypothesize that the karst landscape identified offshore of the Gargano Promontory formed on or at least likely involved this unit at a time of lowered sea level during the late Pleistocene. This hypothesis is supported by the welldeveloped karst features observed on Plio-Pleistocene calcarenites in different coastal settings of the Mediterranean Basin (De Waele et al., 2011). Although lipoclastic, and therefore not as pure as a typical Mesozoic limestone, these Plio-Pleistocene deposits have been intensely affected by karst processes, as pointed out by the widespread occurrence of dolines, often related to underground caves and other macro- and micro-karst landforms dotting their outcropping areas. Thus, the landscape described in this paper seems to resemble the analogous features that were observed in different locations of Apulia.
On the other hand, we cannot exclude the possibility that other units, such as the Peschici or Maiolica Fms, were karstified in this offshore portion of the margin, but available data do not provide any robust supporting evidence.

We hypothesize that any active karstification in the area had to stop due to the postglacial inundation approximately $12 \mathrm{ky} \mathrm{BP}$ that brought on the shelf brackish/ lagoonal and then fully marine conditions when sea level reached $-50 \mathrm{~m}$ in Marine Isotope Stage 1 (Siddall et al., 2003). However, the presence of older brackish/lagoonal marine fauna (Cerastoderma) at Oyster Pit older than $40 \mathrm{ky}$ may well indicate that a depression existed already at that time, thus perhaps moving back the time of karstification to MIS4. The area would have been inundated during the relative high-stand MIS3 (Simms et al., 2009), re-exposed during the MIS2 sea-level drop, and definitely submerged again at $12 \mathrm{ky}$ BP.

At present, there are no signs indicating any on-going karst activity, such as karst springs like those seen in similar contexts in other parts of the Mediterranean Sea (e.g., Cossu et al., 2007; Mijatović, 2007; De Waele, 2009). Hydrologic data acquired from inside the best developed doline, Oyster Pit, support this presumption since there is no anomaly with respect to the surrounding marine water mass (Fig. 12). In our view, therefore, the submerged karst topography is a drowned relic.

\section{Conclusions}

The scenario proposed here to account for the submerged topography recognized off the shore of the Gargano Promontory calls for a subaerially formed karst landscape submerged by the sea. Our main lines of reasoning are:

I. The morphology of some key features, namely the almost perfectly circular shape and vertical profile of depressions punctuating the seafloor reminiscent of dolines on shore.

II. The carbonate nature of the superficial bedrock of this terrigenous-starved sector of the Apulian Adriatic, identified tentatively as Plio-Pleistocene calcarenites, likely the Calcarenite di Gravina Fm, prone to karstification and well documented in outcrop and offshore wells in this region; however, the possible involvement of other carbonate units (Peschici or Maiolica Fms) is not fully discarded, but at present

Fm). 2. Chert with intraclasts (cf. Maiolica Fm). 3. Bioclastic rudstone (Ripe Rosse Fm). 4, 5. Packstone with planktonic forams and bioclasts (cf. Pietra leccese Fm or Calcareniti di Apricena Fm). 6. Polymictic arkosic sandstone. The ${ }^{14} \mathrm{C}-\mathrm{AMS}$ ages relate to brackish-lagoonal mollusks (Cerastoderma) remobilized together with pebbles from the upper part of the doline. (B) Core ARCADIA105, recovered from the bottom of Oyster Pit at 73.4 depth. 


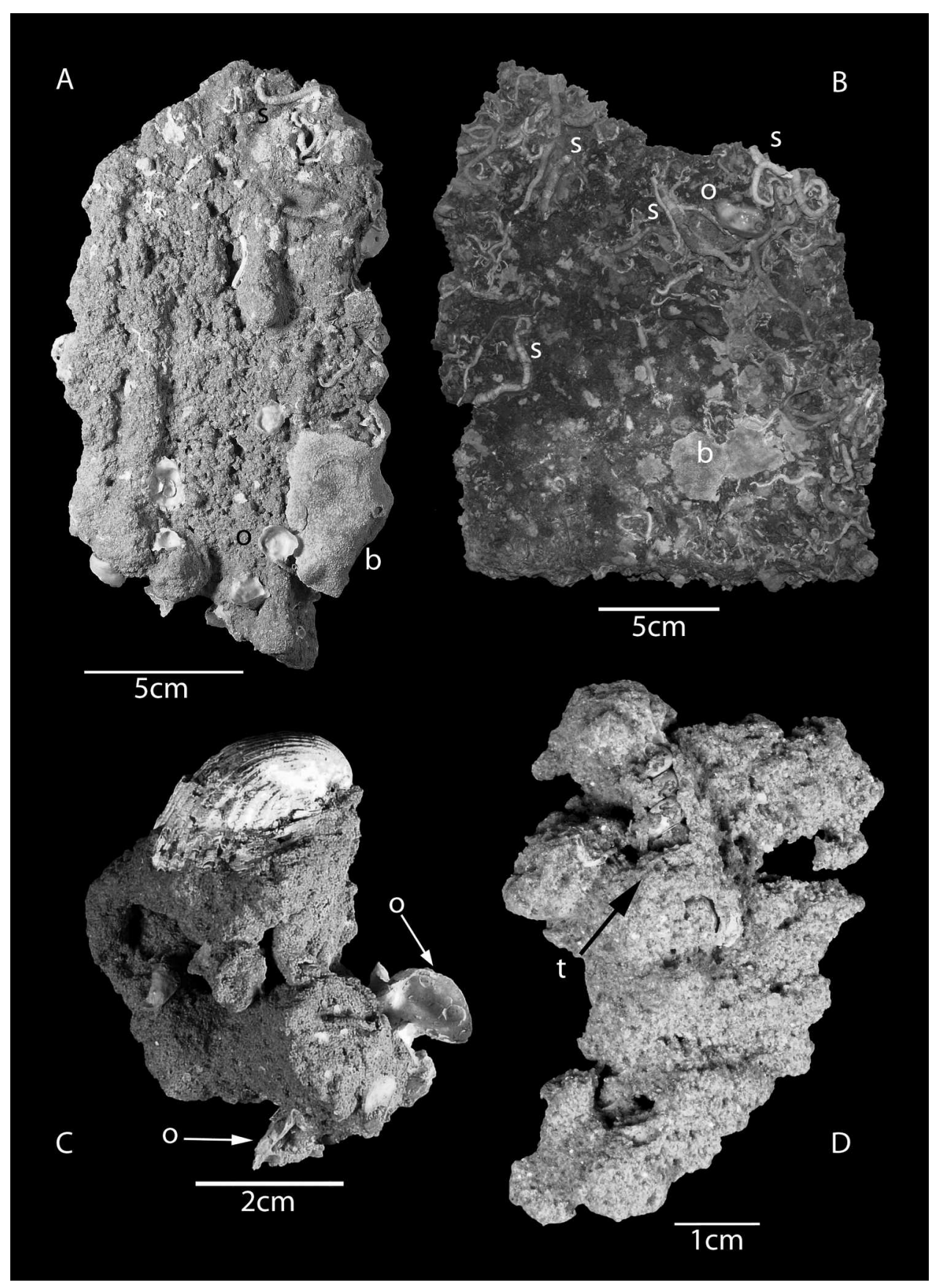

Figure 10. Examples of calcarenites recovered from the drowned karst area and tentatively attributed to the Calcarenite di Gravina Fm. (A) Slab of coarse-grained, porous calcarenite dredged from the bedrock in the rough-topography zone at $42^{\circ} 01.23^{\prime} \mathrm{N}$ and $16^{\circ} 11.23^{\prime} \mathrm{E}, 48 \mathrm{~m}$ water depth (ARCO73). Notice parallel grooves, possibly karren (dissolution micro-karst features), and the surface fouled by modern oysters (Neopycnodonte cochlear) (o), serpulids (s), and bryozoans (b). (B) Flat slab of well-lithified (hardground) calcarenite from the rough-topography zone at $42^{\circ} 00.88^{\prime} \mathrm{N}$ and $16^{\circ} 13.03$ ' $\mathrm{E}, 52 \mathrm{~m}$ water depth (ARCO77). Observe that the surface is fouled by modern oysters (o), serpulids (s), and bryozoans (b) and stained by oxides, an indication of prolonged exposure on the seabottom. (C) Piece of fossiliferous calcarenite from inside Oyster Pit (ARCADIA111, $71 \mathrm{~m}$ ) embedding a decalcified marine bivalve (Acanthocardia sp.) and exploited as an attachment base by modern oysters ( $N$. cochlear, arrows). (D) Piece of fossiliferous calcarenite from inside Oyster Pit (ARCO72, 73 m). Notice the mold (arrow) of a marine gastropod (Turritella sp.). 


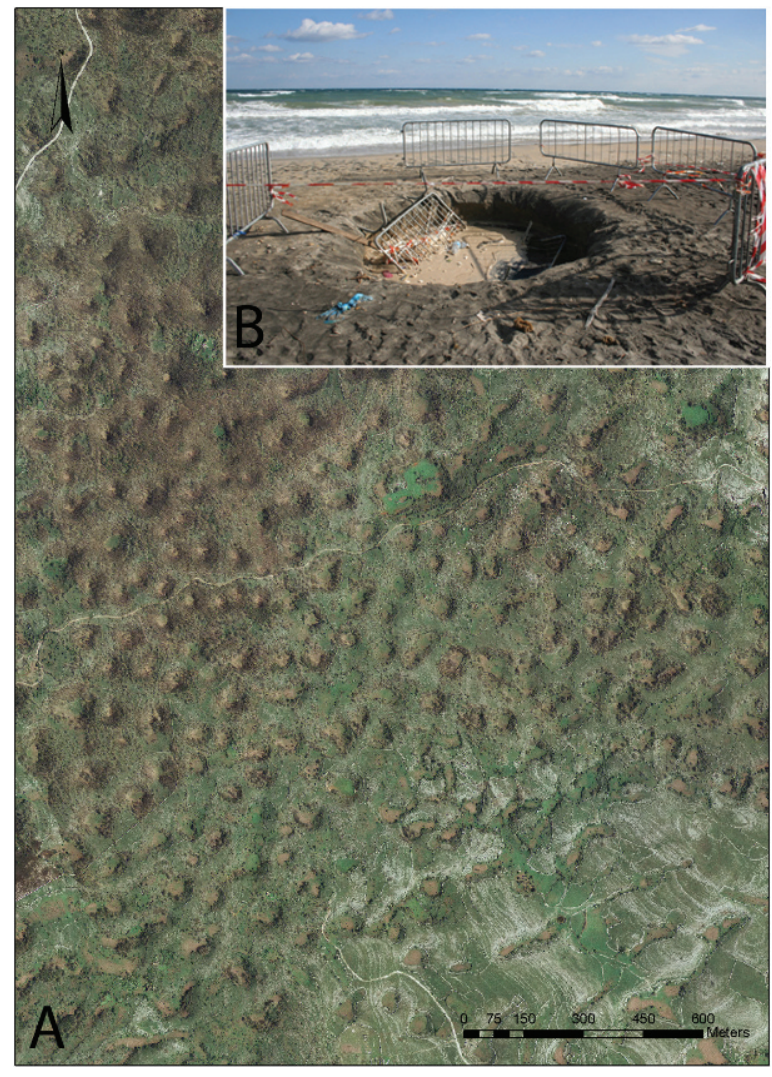

Figure 11. Example of karst landscape on Apulia resembling the submerged features off of the Gargano Promontory. (A) Karst landscape from inland Gargano Promontory near San Giovanni Rotondo (photo downloaded from Google, 2010). (B) Small doline (sinkhole) on the coastline near Lecce at Casalabate, March 2010).

we lack seismic data suitable to image the deeper structure of the dolines to explore this option further.

III. The late Pleistocene sea-level history of the margin, which was repeatedly subaerially exposed during the last glacial cycle, including the major drop at the Last Glacial Maximum, Marine Isotope Stage 2, thus permitting the action of karstification on its carbonate rocks.

\section{ACKNOWLEDGMENTS}

We are grateful to masters, crew, and colleagues onboard RV Urania during missions CNR002, ARCO, and ARCADIA. Thanks are due to ROV specialists Danilo Malatesta (cruise ARCO) and Simone Canese and Lorenzo Rossi (cruise ARCADIA). Alessandro De Lorenzi helped with core sample treatment and Stefano Miserocchi with hydrologic information. Mladen Juračić and two anonymous reviewers are thanked for their critical comments to improve this manuscript. Funding was partially provided by CNR, the EU FP-VI HERMES (GOCE-CT-2005-511234-1), the FP-VII
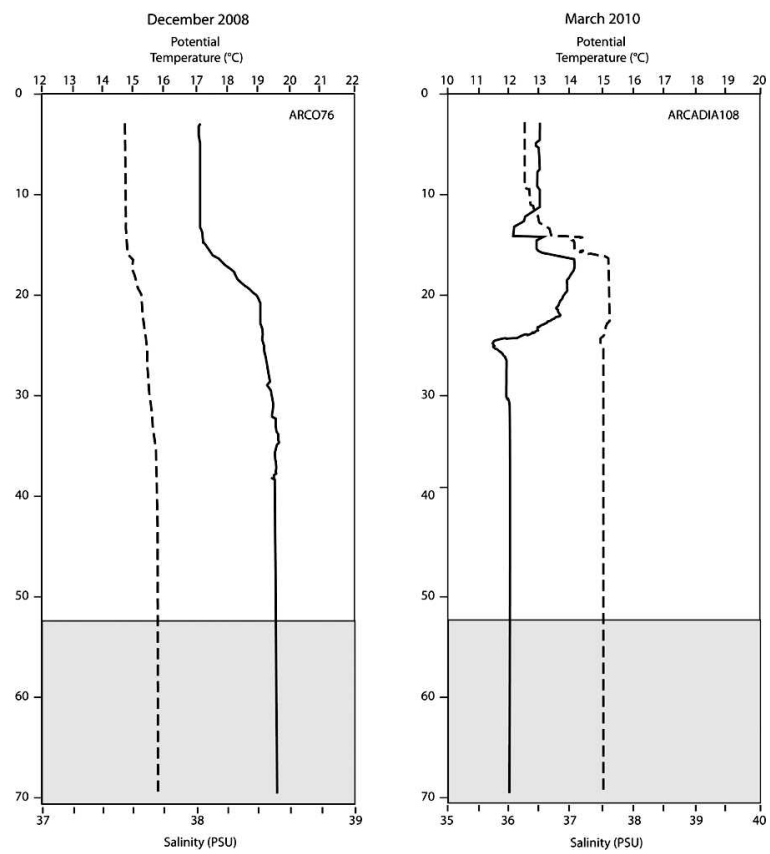

Figure 12. CTD cast hydrologic profiles showing temperature and salinity measured during ARCO (ARCO76, number 12 in Fig. 3, December 2008) and ARCADIA (ARCADIA108, number 12 in Fig. 3, March 2010) missions. No anomalies due to freshwater from springs are detectable, showing instead that seawater within the main doline (gray) is indistinguishable from the overlying Adriatic water at this location.

HERMIONE project (contract number 226354), COCONET (Grant agreement no: 287844), and the Region Apulia BIOMAP projects. This is ISMAR-Bologna scientific contribution number 1707.

\section{REFERENCES}

Argnani, A., Rovere, M., and Bonazzi, C., 2009, Tectonics of the Mattinata fault, offshore south Gargano (southern Adriatic Sea, Italy): Implications for active deformation and seismotectonics in the foreland of the Southern Apennines: Geological Society of America Bulletin, v. 121, p. 1421-1440. doi:10.1130/B26326.1.

Baboci, K., Palmentola, G., and Sansò, P., 1991, Primi risultati dello studio quantitativo delle forme carsiche epigee dei dintorni di S. Marco in Lamis (FG): Itinerari Speleologici, v. 5, p. 87-95.

Biju-Duval, B., Charier, S., Taviani, M., Morel, Y., Baudrimont, A., Burollet, P.F., Clairefond, P., Clauzon, G., Colantoni, P., Mascle, G., Montadert, L., Perrier, R., Orsolini, P., Ravenne, C., and Winnocks, E., 1983, Dépressions circulaires au pied de l'escarpement de Malte et morphologie des escarpements sous-marins. Problèmes d'interprétation: Revue de l'Institut Francais du Petrole, v. 38, no. 5, p. 605-619. doi: 10.2516/ogst:1983036.

Bosellini, A., and Morsilli, M., 2001, Il Promontorio del Gargano: cenni di geologia e itinerari geologici, Quaderni del Parco Nazionale del Gargano, Monte S. Angelo (FG), 48 p.

Bosellini, A., Morsilli, M., and Neri, C., 1999, Long-term event stratigraphy of the Apulia Platform margin (Upper Jurassic to Eocene, Gargano, southern Italy): Journal of Sedimentary Research, v. 69, p. $1241-1252$. 
Bruno, E., Calcaterra, D., and Parise, M., 2008, Development and morphometry of sinkholes in coastal plains of Apulia, southern Italy: Preliminary sinkhole susceptibility assessment. Engineering Geology, v. 99, p. 198-209.

Casolari, E., Negri, A., Picotti, V., and Bertotti, G., 2000, Neogene stratigraphy and sedimentology of the Gargano Promontory (southern Italy): Eclogae Geologicae Helvetiae, v. 93, p. 7-23.

Castiglioni, B., and Sauro, U., 2000, Large collapse dolines in Puglia (southern Italy): the cases of "Dolina Pozzatina" in the Gargano plateau and of "puli" in the Murge: Acta Carsologica, v. 29, p. 83-93.

Cattaneo, A., Correggiari, A., Langone, L., and Trincardi, F., 2003, The late-Holocene Gargano subaqueous delta, Adriatic shelf: Sediment pathways and supply fluctuations: Marine Geology, v. 193, p. 61-91. doi:10.1016/S0025-3227(02)00614-X.

Collina-Girard, J., 1996, Préhistoire et karst: la grotte Cosquer et les Calanques Marseillaises (Bouches-du-Rhône, France): Karstologia, no. 27 , p. $27-40$.

Cossu, A., De Waele, J., and Di Gregorio, F., 2007, Coastal karst geomorphosites at risk? A case study: the floods of 6-11 December 2004 in central-east Sardinia, in Parise, M., and Gunn, J., eds., Natural and Anthropogenic Hazards in Karst Areas: Recognition, Analysis and Mitigation, Geological Society of London Special Publication 279, p. 85-95.

Cvijić, J., 1893, Das karstphänomen: Versuch einer morphologischen Monographie: Geographischen Abhandlung, Wien, v. 5, no. 3, p. 218-319.

De Alteriis, G., and Aiello, G., 1993, Stratigraphy and tectonics offshore of Puglia (Italy, southern Adriatic Sea): Marine Geology, v. 113, p. 233-253. doi:10.1016/0025-3227(93)90020-V.

De Dominicis, A., and Mazzoldi, G., 1987, Interpretazione geologicostrutturale del margine orientale della Piattaforma Apula: Memorie della Società Geologica Italiana, v. 38, p. 163-176.

Delle Rose, M., and Parise, M., 2002, Karst subsidence in south-central Apulia, Italy: International Journal of Speleology, v. 31, no. 1-4, p. 181-199.

Del Prete, S., Iovine, G., Parise, M., and Santo, A., 2010, Origin and distribution of different types of sinkholes in the plain areas of Southern Italy: Geodinamica Acta, v. 23, no. 1-3, p. 113-127. doi:10.3166/ga.23.113-127.

De Waele, J., 2009, Evaluating disturbance on Mediterranean karst areas: the examples of Sardinia (Italy): Environmental Geology, v. 58, p. 239-255. doi:10.1007/s00254-008-1600-x.

De Waele, J., Lauritzen, S.-E., and Parise, M., 2011, On the formation of dissolution pipes in Quaternary coastal calcareous arenites in Mediterranean settings: Earth Surface Processes and Landforms, v. 36, p. 143-157. doi:10.1002/esp.2022.

Eberli, G.P., Bernoulli, D., Sanders, D., and Vecsei, A., 1993, From aggradation to progradation: the Maiella Platform, Abruzzi, Italy, in Simo, J.A.T., Scott, R.W., and Masse, J.-P., eds., Cretaceous Carbonate Platforms, AAPG Memoir 56, p. 213-232.

Elhatip, H., and Günay, G., 1998, Karst hydrogeology of the Kaş-Kalkan springs along the Mediterranean coast of Turkey: Environmental Geology, v. 36, p. 150-158. doi:10.1007/s002540050330.

Fleury, P., Bakalowicz, M., and Cortés, J.M., 2006, Hydrological functioning of a coastal karst with submarine discharge: the case of Moraig-Toix system, Spain, in Durán, J.J., Andreo, B., and Carrasco, F., eds., Karst, Cambio Cimático y Aguas Subterréaneas: Madrid, Publicaciones del Instituo Geológico y Minero de España, Serie Hidrogeología y Aguas Subterráneas 18, p. 145-152.

Ford, D., and Williams, P., 2007, Karst Hydrogeology and Geomorphology, Wiley, London, $562 \mathrm{p}$.

Fusilli, C., 2007, Le grotte pugliesi. Area garganica. In Inguscio, S., Lorusso, D., Pascali, V., Ragone, G., and Savino, G., eds., Grotte e Carsismo in Puglia, Bari, Italy, Regione Puglia, p. 129-136.

Herak, M., and Stringfield, V.T., eds., 1972, Karst: Important Karst Regions of the Northern Hemisphere: Amsterdam, Elsevier, 551 p.

James, N.P., and Choquette, P.W., eds., 1988, Paleokarst: Berlin, SpringerVerlag, $416 \mathrm{p}$

Jennings, J.N., 1985, Karst Geomorphology.Oxford, Basil Blackwell, 293 p.

Land, L.A., and Paull, C.K., 2000, Submarine karst belt rimming the continental slope in the Straits of Florida: Geo-Marine Letters, v. 20, p. 123-132. doi:10.1007/s003670000041.

Land, L.A., Paull, C.K., and Hobson, B., 1995, Genesis of a submarine sinkhole without subaerial exposure: Straits of Florida: Geology, v. 23, p. 949-951. doi:10.1130/0091-7613(1995)023<0949:GOASSW>2.3.CO;2.
Magaldi, M.G., Özgökmen, T.M., Griffa, A., and Rixen, M., 2010, On the response of a turbulent coastal buoyant current to wind events: The case of the Western Adriatic Current: Ocean Dynamics, v. 60, p. 93-122. doi:10.1007/s10236-009-0247-9.

Mijatović, B., 2007, The groundwater discharge in the Mediterranean karst coastal zones and freshwater tapping: set problems and adopted solutions, Case studies. Environmental Geology, v. 51, p. 737-742. doi:10.1007/s00254-006-0390-2.

Nisio, S., ed., 2008, Natural Sinkhole Phenomena in the Italian Plain Areas: Memorie descrittive della Carta Geologica d'Italia 85, 475 p.

Palmer, A.N., 1990, Ground water processes in karst terranes, in Higgins, C.G., and Coates, D.R., eds., Ground water geomorphology; the role of subsurface water in earth-surface processes and landforms: Geological Society of America Special Paper 252, p. 177-209.

Parise, M., 2008a, The sinkholes in the Puglia region, in Nisio, S., ed., Natural sinkhole phenomena in the Italian plain areas, Memorie descrittive della Carta Geologica d'Italia 85, p. 309-334.

Parise, M., 2008b, Elementi di geomorfologia carsica della Puglia: in Parise, M., Inguscio, S., and Marangella, A., eds., Geomorfologia Carsica, Proceedings of the 45th Course CNSS-SSI, Grottaglie, 2-3 February 2008, p. 93-118.

Parise, M., 2011, Surface and subsurface karst geomorphology in the SE Murge (Apulia, southern Italy): Acta Carsologica, v. 40, p. 79-93.

Reimer, P.J., Baillie, M.G.L., Bard, E., Bayliss, A., Beck, J.W., Blackwell, P.G., Bronk Ramsey, C., Buck, C.E., Burr, G.S., Edwards, R.L., Friedrich, M., Grootes, P.M., Guilderson, T.P., Hajdas, I., Heaton, T.J., Hogg, A.G., Hughen, K.A., Kaiser, K.F., Kromer, B., McCormac, F.G., Manning, S.W., Reimer, R.W., Richards, D.A., Southon, J.R., Talamo, S., Turney, C.S.M., van der Plicht, J., and Weyhenmeyer, C.E., 2009, IntCal09 and Marine09 radiocarbon age calibration curves, 0-50,000 years cal BP: Radiocarbon, v. 51, p. 1111-1150.

Ridente, D., and F. Trincardi, 2005, Pleistocene "muddy" forcedregression deposits on the Adriatic shelf: A comparison with prodelta deposits of the late Holocene highstand mud wedge: Marine Geology, v. 222-223, p. 213-233. doi:10.1016/j.margeo.2005.06.042.

Siddall, M., Rohling, E.J., Almogi-Labin, A., Hemleben, Ch., Meischner, D., Schmelzer, I., and Smeed, D.A., 2003, Sea-level fluctuations during the last glacial cycle: Nature, v. 423, p. 853-858. doi:10.1038/nature01690.

Simms, A.R., DeWitt, R., Rodriguez, A.B., Lambeck, K., and Anderson, J.B., 2009, Revisiting marine isotope stage 3 and 5a (MIS3-5a) sea levels within the northwestern Gulf of Mexico: Global and Planetary Change, v. 66, p. 100-111. doi:10.1016/j.gloplacha.2008.03.014.

Surić, M., 2002, Submarine karst of Croatia - Evidence of former lower sea levels: Acta Carsologica, v. 31, no. 3, p. 89-98.

Surić, M., 2005, Submerged karst - dead or alive? Examples from the eastern Adriatic Coast (Croatia): Geoadria, v. 10, p. 5-19.

Surić, M., and Juračić, M., 2010, Late Pleistocene-Holocene environmental changes - records from submerged speleothems along the Eastern Adriatic coast (Croatia): Geologia Croatica, v. 63, no. 2, p. 155-169. doi: $104154 /$ gc. 2010.13 .

Surić, M., Juračić, M., Horvatinčić, N., and Krajcar Bronić, I., 2005, Late Pleistocene-Holocene sea-level rise and the pattern of coastal karst inundation: records from submerged speleothems along the Eastern Adriatic Coast (Croatia). Marine Geology, v. 214/1-3, p. 163-175. doi:10.1016/j.margeo.2004.10.030.

Sweeting, M.M., 1973, Karst Landforms, New York, Columbia University Press, $362 \mathrm{p}$.

Taviani, M., 1984, Submarine "sinkholes": A review, in Beck, B.F., ed., Sinkholes: Their Geology, Engineering and Environmental Impact, Proceedings of the First Multidisciplinary Conference on Sinkholes, Orlando, Florida, 15-17 October 1984, Rotterdam, Balkema, p. 117-121.

Taviani, M., Angeletti, L., Campiani, E., Ceregato, A., Foglini, F., Maselli, V., Trincardi, F., the ARCO Shipboard Staff, 2009, Drowned karst topography and ecosystems offshore Gargano peninsula, southern Adriatic sea, International Interdisciplinary Scientific Conference, Sustainability of the Karst Environment - Dinaric Karst and Other Karst Regions, Plitvice Lakes, Croatia, Abstracts, 132 p.

van Hengstum, P.J., Scott, D.B., Gröcke, D.R., and Charette, M.A., 2011, Sea level controls sedimentation and environments in coastal caves and sinkholes. Marine Geology, v. 286, p. 35-50. doi:10.1016/ j.margeo.2011.05.004.

Waltham, T., Bell, F., and Culshaw, M., 2005, Sinkholes and subsidence: karst and cavernous rocks in engineering and construction: Berlin, Springer, $382 \mathrm{p}$. 